\title{
Transient Neonatal Diabetes Mellitus in a Turkish Patient with Three Novel Homozygous Variants in the ZFP57 Gene
}

\author{
Mehmet Boyraz ${ }^{*}$, Korkut Ulucan2*, Necati Taşkın3, Teoman Akçay4, Sarah E. Flanagan5, \\ Deborah J.G.Mackay6 \\ ${ }^{1}$ Şişli Etfal Education and Research Hospital, Division of Pediatric Endocrinology, Istanbul, Turkey \\ 2 Üsküdar University, Faculty of Engineering and Natural Sciences, Department of Molecular Biology and Genetics, Istanbul, Turkey \\ ${ }^{3}$ Kanuni Sultan Süleyman Education and Research Hospital, Division of Pediatrics, Istanbul, Turkey \\ ${ }^{4}$ Sadi Konuk Education of Research Hospital, Division of Pediatric Endocrinology, Istanbul, Turkey \\ 5 Peninsula College of Medicine and Dentistry, Division of Molecular Genetics, Exeter, UK \\ 6 University of Southampton, School of Medicine, Human Genetics Research Division, Salisbury, UK
}

${ }^{*}$ Both authors contributed equally to this work

\section{ABSTRACT}

Neonatal diabetes mellitus (NDM) is a rare form of diabetes that presents within the first six months of life. Nearly $70 \%$ of these cases have loss of methylation at the differentially methylated region on chromosome $6 q 24$. To describe the findings in a Turkish male patient with NDM caused by a loss of methylation at chromosome 6q24 and three novel homozygous mutations in the ZFP57 gene, methylation-specific PCR was carried out at 6q24 and mutation analysis of ZFP57 gene was maintained by direct sequencing. Sequencing of ZFP57 gene revealed the hypomethylation of chromosome 6q24 and three novel mutations (chr6:29.641.413 A>T, 29.641.073 C>T, and 29.640.855 G>C), respectively. The latter mutation seems to display the patient's condition due to a highly conservative amino acid substitution in the protein. We suggest the ZFP57gene as a causative factor for NDM and it should be considered in genetic testing. Further studies including functional analysis of the detected mutations will provide precise information regarding the effect of the mutations. Key words: ZFP57 gene, transient neonatal diabetes mellitus, Turkish, novel mutations

Conflict of interest: None declared

Received: 07.01.2013

Accepted: 09.04 .2013

\section{Introduction}

Neonatal diabetes mellitus (NDM) is a rare form of diabetes with an incidence of 1/90000 live births. It is defined as diabetes that presents within the first six months of life, persists for at least two weeks, and requires insulin treatment (1). The outcome is highly variable with approximately $40-50 \%$ of patients with permanent NDM (PNDM) and $50-60 \%$ with transient NDM (TNDM). TNDM resolves postnatally, but may relapse in later life $(2,3)$. Approximately $70 \%$ of TNDM cases have loss of methylation at the differentially methylated region (DMR) on chromosome 6q24. Loss of methylation can result from one of three genetic mechanisms: 1) paternal uniparental disomy 2) paternal duplication, or 3) loss of methylation without a structural chromosome defect. The critical region on chromosome 6q24 encompasses PLAGL1, a tumor suppressor gene, and $H Y M A l$, a non-coding RNA of unknown function. The mechanism(s) by which loss of methylation, and hence overexpression of PLAGL 1 and/or HYMAI cause TNDM is not known $(4,5)$. Approximately $50 \%$ of TNDM patients with a loss of methylation and no structural chromosome defect at

Address for Correspondence

Korkut Ulucan PhD, Üsküdar University, Faculty of Engineering and Natural Sciences, Department of Molecular Biology and Genetics, Istanbul, Turkey Phone: +90 21640022 22/2409 E-mail: korkutulucan@hotmail.com

O Journal of Clinical Research in Pediatric Endocrinology, Published by Galenos Publishing. 
chromosome 6q24 have hypomethylation of imprinted loci (HIL) throughout the genome which in many cases results in a syndromic phenotype (6). In a proportion of these patients, recessive mutations in ZFP57 gene are identified. ZFP57 encodes a zinc-finger transcription factor expressed in early development, which is thought to be involved in DNA methylation during the earliest multicellular stages at multiple imprinting control regions (6)

Here, we describe a Turkish patient with TNDM caused by a loss of methylation at the chromosome 6q24 locus and three novel homozygous missense variants in the ZFP57 gene.

\section{Case Presentation}

A 12-day-old male was referred from another clinic due to feeding difficulties, lethargy, and hyperglycemia. The patient was born to healthy first-degree cousins at 36 weeks' gestation by cesarean section delivery with a birth weight of $2040 \mathrm{~g}$ and birth length of $45 \mathrm{~cm}$ (both $<3^{\text {rd }}$ percentile). Physical examination did not reveal any dysmorphic features. His weight was $2050 \mathrm{~g}$ at admission. He was not receiving parenteral nutrition, and sepsis markers were negative. Hyperglycemia persisted without metabolic acidosis or ketonuria. Laboratory investigations revealed a serum C-peptide of $0.1 \mathrm{nmol} / \mathrm{L}$ (normal range, 0.29-1.32 $\mathrm{nmol} / \mathrm{L}$ ), a serum insulin level of $48.2 \mathrm{pmol} / \mathrm{L}$ (normal range, 18-186 pmol/L) and a simultaneous blood glucose level of $28 \mathrm{nmol} / \mathrm{L}$. HbA1c was $2.7 \%$ (normal range, 2.1-7.7\%). There was no evidence of autoimmunity (negative insulin antibodies, glutamic acid decarboxylase antibodies, and islet cell antibodies). Abdominal ultrasonography demonstrated a normal pancreas anatomy. Function studies of other endocrine glands, such as the thyroid and adrenal glands, also revealed normal results. The patient's brother, who is currently 10 years of age, was diagnosed with NDM, which remitted at the age of 15 days. Neither of the patient's parents had symptoms of diabetes. The parents' and brother's fasting blood glucose levels were within normal limits.

The patient was started on continuous intravenous rapid acting insulin therapy $(0.5 \mathrm{U} / \mathrm{kg} /$ day) with strict blood glucose monitoring by bedside capillary glucose testing. A high caloric intake was maintained, and a satisfactory weight gain was accomplished. On the 18th day of life, insulin therapy was changed from intravenous infusion to subcutaneous neutral protamine Hagedorn (NPH), with progressive metabolic control. Hypoglycemia developed several times during insulin therapy. The patient was discharged after resolution of hyperglycemia. He remained on NPH insulin treatment until 6 months of age.

At the age of 6 months, and following the genetic diagnosis, the patient entered remission at which stage insulin treatment was withdrawn. The patient is currently 12 months of age. His growth and physical development are normal.

\section{Molecular Studies}

Genetic profiles were programmed for outpatient followup. Genomic DNA was extracted from the peripheral blood of the patient and family members using the High Pure PCR Template Preparation kit (Roche Diagnostics, Mannheim, Germany). The parents provided their written informed consent, and the study was conducted in compliance with the declaration of Helsinki (2000). ABCC8, KCNJ11, INS, and EIF2AK3 genes were sequenced, and no mutations were detected. In addition to these, methylation-specific PCR of the patient's DNA showed complete loss of maternal methylation at the PLAGL1 DMR on chromosome 6q24, confirming a diagnosis of TNDM due to 6q24 hypomethylation.

DNA methylation was analyzed at other known imprinted regions, using methods as described (7). In addition to the PLAGL1 DMR, DNA hypomethylation was detected at the GRB10, PEG3, and NESP-AS regions, but not at the MEST, ICR1, ICR2, 14q32, or SNRPN regions. This pattern of hypomethylation has been previously observed in individuals with TNDM and mutation of the ZFP57 gene (7).

Coding regions of ZFP57, with intron-exon boundaries, were sequenced in the patient and his parents. The patient had three novel homozygous coding variants, p.T139S (chr6:29,641,413A>T), p.S252F (chr6:29,641,073C>T), and p.A325P (chr6:29,640,855G>C) (Figure 1), and all three were found in heterozygous form in the parents.

These results were consistent with a diagnosis of TNDM-HIL resulting from homozygous variation/s of ZFP57. Both parents were heterozygous for these changes. While p.T139S and p.S252F were not present in dbSNP137 (http:// www.ncbi.nlm.nih.gov/SNP/) or the Exome Variant Server (http://evs.gs.washington.edu/EVS/), p.A325P was present

\begin{tabular}{|c|c|c|c|c|}
\hline Variant & Sequencing electropherogram & \multicolumn{3}{|c|}{ Conservation } \\
\hline $\begin{array}{l}\text { 29,641,413A>T: } \\
139 \text { Thr>Ser } \\
\text { dbSNP137. } \\
\text { EVS. }\end{array}$ & & $\begin{array}{l}\text { Human } \\
\text { Rhesus } \\
\text { Horse } \\
\text { Dog } \\
\text { piq } \\
\text { Mouse } \\
\text { Xenopus } \\
\text { zebrafish }\end{array}$ & 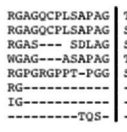 & 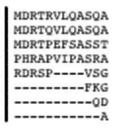 \\
\hline $\begin{array}{l}\text { 29,641,073C>T: } \\
252 \text { Ser>Phe } \\
\text { dbSNP137. } \\
\text { EVS. }\end{array}$ & & 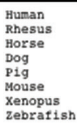 & 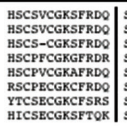 & 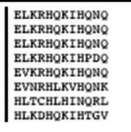 \\
\hline $\begin{array}{l}\text { 29,640,855G >C: } \\
\text { 325 Ala>Pro } \\
\\
\text { dbSNP137: } \\
\text { rs200537697 } \\
\text { EVS } 0.002\end{array}$ & & $\begin{array}{l}\text { Human } \\
\text { Rhesus } \\
\text { Horse } \\
\text { Dog } \\
\text { Pig } \\
\text { Mouse } \\
\text { Rounous } \\
\text { zebrat1sh }\end{array}$ & 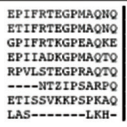 & 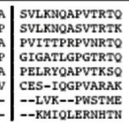 \\
\hline
\end{tabular}

Figure 1. Variants of ZFP57 gene (first column), electropherogram results of sequencing (middle column) and amino acid conservation (left column) 
Boyraz $\mathrm{M}$ et al.

ZFP57 Gene Variations in Transient Neonatal Diabetes Mellutus Patient

in dbSNP137 as rs200537697 with a minor allele frequency of $0.15 \%$. p.T139S and p.A325P were changes found within other placental mammals (Figure 1) and were located within relatively weakly conserved stretches of amino acids. By contrast, p.S252F was present in the highly-conserved zinc finger region responsible for DNA binding (8) and, moreover, near to other known variants associated with TNDM-HIL $(7,9)$. Therefore, it seems likely that p.S252F is the variant responsible for the patient's condition.

\section{Discussion}

NDM is defined as hyperglycemia occurring in the first 6 months of life $(10,11)$. The understanding of the molecular basis for NDM has advanced in recent years. Clinically, this condition can be divided into two categories (TNDM and PNDM), which differ from each other in the resolution or persistence by 18 months of age. However, relapse in childhood or adolescence occurs in up to $50 \%$ of cases. Changes in insulin requirements and changes in the number of pancreatic beta cells have been implicated as the cause of this biphasic course, while the exact mechanism remains undetermined (10).

Our patient had been receiving NPH insulin injections for glycemic control before the mutation analysis which excluded ABCC8, KCNJ11, INS, and EIF2AK3 mutations and demonstrated the presence of a methylation abnormality on $6 q 24$. Previous reports have indicated that oral sulfonylurea therapy in patients with mutations of the KATP channel genes, $A B C C 8$ and $K C N J 11$, can result in glycemic control that is as good, or better, than that achieved with subcutaneous insulin injection $(11,12,13,14)$. Based on the analysis result of our patient, treatment with a sulfonylurea was not initiated as there was already sufficient control with insulin therapy.

ZFP57 gene encodes a zinc-finger protein. Recent studies indicate that ZFP57 is a regulator of transcription required for maintenance of imprinting $(15,16)$, while in humans, this gene has been associated with TNDM $(7,9)$. Novel variation at position $3519 \mathrm{~A}>\mathrm{T}$, a transversion change within the gene, leads to the substitution of amino acid threonine to the similarly polar and uncharged serine at position 139 (T139S), while a G>C transversion at position 4077 causes substitution of alanine by the similarly non-polar proline residue (A325P). Both these variations are in relatively nonconserved stretches of amino acids, and the second of them is a recognized though rare SNP. A third novel variation, 3859 $A>T$, substituted amino acid serine to phenylalanine (S252F). $\mathrm{X}$-ray crystallography studies predict that this substitution is in the highly conserved DNA-binding zinc-finger region of ZFP57, and therefore has an impact on its DNA binding. By the sequencing of gene, we showed the three novel variations in the patient, but we are still far from identifying the effect of these variants on the function of ZFP57 and therefore its physiological effects on our patient.

In conclusion, ZFP57 gene is an important genetic determinant for the onset of TNDM. Considering testing for this gene in diagnosed cases will help clinicians to have more knowledge regarding the effect of variations detected in the gene sequence on the disease. It is difficult to comment on the effect of these changes we detected in this report. Further studies, including analyses of the same gene of the patients' brother and functional analysis of the gene will help us have more precise information on these newly detected changes.

\section{References}

1. Arthur El, Zlotogora J, Lerer I, Dagan J, Marks K, Abeliovich D. Transient neonatal diabetes mellitus in a child with invdup(6) (q22q23) of paternal origin. Eur J Hum Genet 1997;5:417-419.

2. von Mühlendahl KE, Herkenhoff $H$. Long-term course of neonatal diabetes. N Engl J Med 1995;333:704-708.

3. Polak M, Cavé H. Neonatal diabetes mellitus: a disease linked to multiple mechanisms. Orphanet J Rare Dis 2007;2:12.

4. Suzuki S, Makita Y, Mukai T, Matsuo K, Ueda O, Fujieda K Molecular basis of neonatal diabetes in Japanese patients. J Clin Endocrinol Metab 2007;92:3979-3985. Epub 2007 Jul 17

5. Gardner RJ, Mackay DJ, Mungall AJ, Polychronakos C, Siebert R, Shield JP, Temple IK, Robinson DO. An imprinted locus associated with transient neonatal diabetes mellitus. Human Mol Genet 2000;9:589-596.

6. Mackay DJ, Boonen SE, Clayton-Smith J, Goodship J, Hahnemann JM, Kant SG, Njølstad PR, Robin NH, Robinson DO, Siebert R, Shield JP, White HE, Temple IK. A maternal hypomethylation syndrome presenting as transient neonatal diabetes mellitus. Hum Genet 2006;120:262-269. Epub 2006 Jul 1

7. Mackay DJ, Callaway JL, Marks SM, White HE, Acerini CL, Boonen SE, Dayanikli P, Firth HV, Goodship JA, Haemers AP, Hahnemann JM, Kordonouri $O$, Masoud $A F$, Oestergaard E, Storr J, Ellard S, Hattersley AT, Robinson DO, Temple IK. Hypomethylation of multiple imprinted loci in individuals with transient neonatal diabetes is associated with mutations in ZFP57. Nat Genet 2008;40:949-951. Epub 2008 Jul 11

8. Liu Y, Toh H, Sasaki H, Zhang X, Cheng X. An atomic model of Zfp57 recognition of CpG methylation within a specific DNA sequence. Genes Dev 2012;26:2374-2379. Epub 2012 Oct 11

9. Boonen SE, Mackay DJ, Hahnemann JM, Docherty L, Grønskov K, Lehmann A, Larsen LG, Haemers AP, Kockaerts Y, Dooms L, Vu DC, Ngoc CT, Nguyen PB, Kordonouri O, Sundberg F, Dayanikli P, Puthi $V$, Acerini C, Massoud AF, Tümer Z, Temple IK. Transient neonatal diabetes, ZFP57, and hypomethylation of multiple imprinted loci: a detailed follow-up. Diabetes Care 2013;36:505-512. Epub 2012 Nov 12

10. Flanagan SE, Patch AM, Mackay DJ, Edghill EL, Gloyn AL, Robinson D, Shield JP, Temple K, Ellard S, Hattersley AT. Mutations in ATP-sensitive $\mathrm{K}+$ channel genes cause transient neonatal diabetes and permanent diabetes in childhood or adulthood. Diabetes 2007;56:1930-1937. Epub 2007 Apr 19

11. Nakhla M, Polychronakos C. Monogenic and other unusual causes of diabetes mellitus. Pediatr Clin North Am 2005;52:1637-1650. 
Boyraz $\mathrm{M}$ et al.

ZFP57 Gene Variations in Transient Neonatal Diabetes Mellutus Patient

12. Rafiq M, Flanagan SE, Patch AM, Shields BM, Ellard S, Hattersley AT; Neonatal Diabetes International Collaborative Group. Effective treatment with oral sulfonylureas in patients with diabetes due to sulfonylurea receptor 1 (SUR1) mutations. Diabetes Care 2008;31:204-209. Epub 2007 Nov 19

13. Babenko AP, Polak $M$, Cavé $H$, Busiah $K$, Czernichow $P_{1}$ Scharfmann R, Bryan J, Aguilar-Bryan L, Vaxillaire M, Froguel P. Activating mutations in the ABCC8 gene in neonatal diabetes mellitus. N Engl J Med 2006;355:456-466.

14. Tonini G, Bizzarri C, Bonfanti R, Vanelli M, Cerutti F, Faleschini E, Meschi F, Prisco F, Ciacco E, Cappa M, Torelli C, Cauvin V, Tumini S, lafusco D, Barbetti F; Early-Onset Diabetes Study Group of the Italian Society of Paediatric Endocrinology and Diabetology. Sulfonylurea treatment outweighs insulin therapy in short-term metabolic control of patients with permanent neonatal diabetes mellitus due to activating mutations of the KCNJ11 (KIR6.2) gene. Diabetologia 2006;49:2210-2213. Epub 2006 Jul 1

15. Li X, Ito M, Zhou F, Youngson N, Zuo X, Leder P, Ferguson-Smith AC. A maternal-zygotic effect gene, Zfp57, maintains both maternal and paternal imprints. Dev Cell 2008:15:547-557.

16. Quenneville S, Verde G, Corsinotti A, Kapopoulou A, Jakobsson J, Offner S, Baglivo I, Pedone PV, Grimaldi G, Riccio A, Trono D. In embryonic stem cells, ZFP57/KAP1 recognize a methylated hexanucleotide to affect chromatin and DNA methylation of imprinting control regions. Mol Cell 2011;44:361-372. 